\title{
Localization and Characterization of Lipolytic Enzymes Produced by Lysobacter enzymogenes
}

\author{
By RICHARD G. VON TIGERSTROM* AND SHEILAH STELMASCHUK \\ Department of Microbiology, University of Alberta, Edmonton, Alberta T6G 2E9, Canada
}

(Received 4 July 1988; revised 20 December 1988; accepted 4 January 1989)

Lipolysis by Lysobacter enzymogenes is due to the production of two major extracellular esterases. These were investigated using a turbidimetric assay with Tween 20 as the substrate. One esterase is cell-associated and found in the particulate fraction of cell-free extracts, the other esterase is secreted into the culture medium. In batch culture with $0.8 \%$ yeast extract as the medium the particulate esterase was produced mainly during the exponential growth phase and its yield was increased about twofold by the addition of olive oil and other substrates. The supernatant esterase was produced mainly after the exponential growth phase and was induced six- to tenfold by olive oil. PAGE, combined with activity staining using Tween 20 as the substrate, indicated that the two enzymes have different electrophoretic mobilities. Intact cells expressed $87 \%$ of the particulate cell-associated esterase activity. The enzyme was released from cells or from the particulate fraction by incubation with $0.2 \%$ Zwittergent $3-14$. Tween $20(2 \%$, $\mathrm{v} / \mathrm{v}$ ) or $1 \mathrm{mM}$-EDTA released little of the enzyme from whole cells. Separation of the inner and outer membranes of $L$. enzymogenes showed that the particulate esterase was localized in the outer membrane. Both esterases were very active with Tween 20 as the substrate, but they hydrolysed other compounds at very different rates. The relative activities with Tween 20 , $p$-nitrophenyl palmitate, tributyrin and olive oil were 100,3,11 and 0 for the particulate esterase and 100, 73, 0 and 28 for the secreted esterase. In addition to these two extracellular esterases, L. enzymogenes contains a hydrolase in the cytoplasm which is most active with tributyrin.

\section{INTRODUCTION}

The genus Lysobacter contains Gram-negative gliding bacteria which are noted for the production of many extracellular enzymes and for their role in biodegradation (Christensen \& Cook, 1978; Reichenbach \& Dworkin, 1981; Rosenberg \& Varon, 1984). All species of the genus, except two strains of Lysobacter brunescens, were found to hydrolyse Tween when tested on solid media containing this detergent (Christensen \& Cook, 1978). A number of the extracellular enzymes produced by Lysobacter species have been characterized (Jackson \& Matsueda, 1970; Whitaker, 1970; Hedges \& Wolfe, 1974; von Tigerstrom, 1980, 1981, 1984; von Tigerstrom \& Stelmaschuk, 1986, 1987 b), but the enzymes responsible for the lipase activity have not been investigated.

Preliminary experiments indicated that $L$. enzymogenes produces two extracellular Tweendegrading hydrolases: one associated with the cells, the other secreted into the culture medium. Although the secreted enzyme can use olive oil as a substrate and might be called a lipase (Jensen, 1983), both enzymes prefer water-soluble substrates and for this reason we call the enzymes esterases rather than lipases (Sugiura, 1984).

This paper describes the production of the two esterases by L. enzymogenes under different culture conditions, the major differences between the two enzymes and the localization of the cell-associated esterase.

Abbreviations: pNPP, p-nitrophenyl palmitate; KDO, 2-keto-3-deoxyoctonate (3-deoxy-D-manno-2octulosonate). 


\section{METHODS}

Chemicals. The substrates used for the enzyme assays were obtained from Sigma except the $\beta$-lactamase substrate (PADAC) which was from Calbiochem. Phosphorylase $b$ and cytochrome $c$ also were from Sigma and the other protein standards for the SDS-PAGE were from Pierce. Catalase from bovine liver was obtained from Calbiochem and Escherichia coli $\mathrm{C}_{4} \mathrm{~F}_{1}$ phosphatase was prepared in this laboratory (von Tigerstrom, 1983).

Organisms and culture conditions. Lysobacter enzymogenes UASM 495 (ATCC 2987) and the other Lysobacter species were obtained from Dr F. D. Cook, University of Alberta. Except where indicated otherwise, liquid cultures were grown at $22{ }^{\circ} \mathrm{C}$ in $0.8 \%(\mathrm{w} / \mathrm{v})$ yeast extract, $0.1 \%(\mathrm{v} / \mathrm{v})$ olive oil as described earlier (von Tigerstrom, 1980). The olive oil was not emulsified. It was added to the medium before autoclaving and became dispersed during the shaking of the culture. The minimal medium contained $15 \mathrm{~mm}$-potassium phosphate, $7.6 \mathrm{~mm}-$ $\left(\mathrm{NH}_{4}\right)_{2} \mathrm{SO}_{4}, 0.5 \mathrm{mM}-\mathrm{MgCl}_{2}, 0.2 \%$ sodium aspartate, $0.5 \%$ glucose, $0.5 \mu \mathrm{g} \mathrm{FeSO}_{4} \mathrm{ml}^{-1}$ and trace metals, $\mathrm{pH} 7.2$. The cultures were harvested, usually in the stationary growth phase, by centrifugation at $16300 \mathrm{~g}$ for 15 min at $4{ }^{\circ} \mathrm{C}$ to obtain the cells and the culture supernatant. This removed $99.99 \%$ of the viable cells from the culture supernatant. The cell-free extract was prepared by suspending the cells in $10 \mathrm{mM}-\mathrm{Tris} / \mathrm{HCl}, 50 \mathrm{mM}-\mathrm{NaCl}, 1 \cdot 5 \mathrm{M}-$

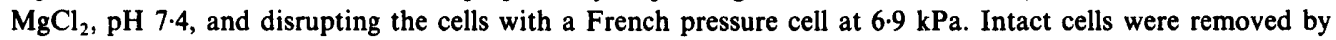
centrifugation at $3020 \mathrm{~g}$ for $15 \mathrm{~min}$.

Enzyme assays. Esterase activities were determined routinely by a turbidimetric assay using Tween 20 as the substrate (von Tigerstrom \& Stelmaschuk, 1989). The assay solution contained $20 \mathrm{mM}-\mathrm{Tris} / \mathrm{HCl}, 1.8 \%$ (v/v) Tween $20,3 \mathrm{mM}-\mathrm{CaCl}_{2}, \mathrm{pH} 8.5$. The increase in the optical density at $500 \mathrm{~nm}\left(\mathrm{OD}_{500}\right)$ was determined at $37^{\circ} \mathrm{C}$ after addition of the enzyme source. A volume of $0.3 \mathrm{ml}$ of enzyme source, containing up to 0.15 units of activity, was added to $3.7 \mathrm{ml}$ of assay solution. Samples of $0.9 \mathrm{ml}$ were removed at timed intervals to determine the $\mathrm{OD}_{500}$. The rate of increase of $\mathrm{OD}_{500}$ was linear up to $\mathrm{OD}_{500} 1.2$ and the rate of increase was essentially zero without added enzyme source. The spectrophotometric esterase assay with p-nitrophenyl palmitate (pNPP) (Winkler \& Stuckman, 1979) and the titrimetric assay with olive oil and tributyrin have been described previously (von Tigerstrom \& Stelmaschuk, 1989).

Cell-free extracts and cells incubated with $0.2 \%(\mathrm{w} / \mathrm{v})$ Zwittergent 3-14 for $30 \mathrm{~min}$ at $37^{\circ} \mathrm{C}$ were used as sources of the cell-associated esterase and the culture supernatants as the source of the supernatant esterase. These were diluted with $20 \mathrm{mM}-\mathrm{Tris} / \mathrm{HCl}, \mathrm{pH} 8.0$, if necessary. The activity of the cell-associated esterase was twofold higher at $37^{\circ} \mathrm{C}$ than at $22^{\circ} \mathrm{C}$ and the supernatant esterase had the same activity at both temperatures. The cell-associated enzyme was stable for at least $2 \mathrm{~h}$ at $22^{\circ} \mathrm{C}$ and $37^{\circ} \mathrm{C}$ and the secreted enzyme was stable for at least $2 \mathrm{~h}$ at $22^{\circ} \mathrm{C}$ and lost only $10 \%$ of its activity in $2 \mathrm{~h}$ at $37^{\circ} \mathrm{C}$. The presence of Zwittergent 3-14 had little or no effect on the stabilities.

Catalase (Chance \& Maehly, 1955), alkaline phosphatase (von Tigerstrom, 1984), NADH oxidase (Osborne $e t$ al., 1972) and glucose-6-phosphate dehydrogenase (DeMoss, 1955) were assayed as described in the references. $\beta$-Lactamase was assayed by following the absorbance at $570 \mathrm{~nm}$ of an assay solution containing $50 \mathrm{~mm}$ potassium phosphate, $4 \mu \mathrm{g}$ PADAC ml ${ }^{-1}, \mathrm{pH} 7 \cdot 0$. Enzyme activities are expressed in units. In the catalase assay, 1 unit = a change of $1 A_{230}$ unit $\min ^{-1}$. For all other enzymes, 1 unit $=1 \mu \mathrm{mol}$ product formed $\min ^{-1}$. It was established by comparison with a titrimetric assay that a change of $1.0 \mathrm{OD}_{500}$ unit in the turbidimetric assay with Tween 20 is equivalent to the release of $0.91 \mu \mathrm{mol}$ fatty acid (ml of reaction mixture) $)^{-1}$.

Polyacrylamide gel electrophoresis. Electrophoresis was carried out on slabs of $10 \%(\mathrm{w} / \mathrm{v})$ polyacrylamide using the method of Maizel (1971), as described earlier (von Tigerstrom \& Stelmaschuk, 1985). The protein standards were prepared under the usual denaturing conditions. The esterase preparations were dialysed against $10 \mathrm{~mm}$ Tris $/ \mathrm{HCl}, \mathrm{pH} 8.0$, and, in order to preserve the enzymic activities, they were made to $1 \%(\mathrm{w} / \mathrm{v})$ SDS just before application and were not heated. Staining for protein was done by the method of Fairbanks et al. (1971). To locate the esterase activity in gels, the gels were blotted briefly to remove excess moisture and overlaid with $1 \%(\mathrm{w} / \mathrm{v})$ agarose, $50 \mathrm{~mm}$-Tris/HCl, $1.8 \%$ (v/v) Tween 20, $3 \mathrm{mM}-\mathrm{CaCl}_{2}, \mathrm{pH} 8.5$, on 'Gel Bond Film' (Marine Colloids Division, FMC Corporation). They were then incubated at $37^{\circ} \mathrm{C}$ for about $30 \mathrm{~min}$, or until bands of precipitation developed in the overlay. The overlay was photographed against a dark background or the positions of the bands were marked on the 'Gel Bond Film' in order to obtain a permanent record of the activity stain.

Separation of cell wall components. This was done by sucrose gradient centrifugation using the method of Hancock \& Nakaido (1978). The details of the procedure used for L. enzymogenes have been reported (von Tigerstrom \& Stelmaschuk, 1985).

Preparation of shock fluid. Cells grown to early stationary phase were subjected to the $\mathrm{MgCl}_{2}$-shocking procedure of Cheng et al. (1970) as described in detail for L. enzymogenes (von Tigerstrom \& Stelmaschuk, 1985). A cell-free extract was prepared from the shocked cells as described above and this was centrifuged for 60 min to obtain the particulate fraction $(48000 \mathrm{~g}$ pellet) and the cytoplasmic fraction $(48000 \mathrm{~g}$ supernatant).

Glycerol gradient centrifugation. To obtain an estimate of the $M_{\mathrm{r}}$ of the native $L$. enzymogenes esterases, the enzymes were treated with $0.2 \%(\mathrm{w} / \mathrm{v}) \mathrm{Zwittergent} 3-14$ in $10 \mathrm{mM}-\mathrm{Tris} / \mathrm{HCl}, \mathrm{pH} 8 \cdot 0$, and centrifuged through a glycerol gradient as described by von Tigerstrom \& Stelmaschuk (1986), except that the gradient also contained $0.05 \%(\mathrm{w} / \mathrm{v})$ Zwittergent 3-14. Catalase $\left(M_{\mathrm{r}} 230000\right)$, Escherichia coli alkaline phosphatase $\left(M_{\mathrm{r}} 84000\right)$, ovalbumin $\left(M_{\mathrm{r}} 45000\right)$ and cytochrome $\mathrm{c}\left(M_{\mathrm{r}} 12500\right)$ were also used as the standards. 
Analytical methods. Protein concentrations were determined by the Lowry method. Controls were included to correct for interference due to buffer components and detergents. The absorbance at $280 \mathrm{~nm}\left(A_{280}\right)$ was used to estimate the protein in the fractions of the sucrose and glycerol gradients. In the sucrose gradients approximately $50 \%$ of the $A_{280}$ values was due to turbidity. Cytochrome $c$ was detected by determining the $A_{280}$ and the $A_{530}$. Concentrations of 2-keto-3-deoxyoctonate (KDO) were estimated according to the method of Law \& Slepecky (1961).

\section{RESULTS AND DISCUSSION}

\section{Esterase production}

The esterase production by different species of Lysobacter was determined. We found that $L$. antibioticus, L. enzymogenes and $L$. gummosus produced similar levels of cell-associated esterase [from 0.4 to 0.7 units ( $\mathrm{ml}$ of culture) ${ }^{-1}$ ] in $0.8 \%(\mathrm{w} / \mathrm{v})$ tryptone broth when grown to $\mathrm{OD}_{600}$ values of $2 \cdot 0,2 \cdot 7$ and $2 \cdot 9$, respectively. $L$. brunescens produced only about $0 \cdot 1$ unit $\mathrm{ml}^{-1}$ when grown to $\mathrm{OD}_{600} 1.7$ in the same medium supplemented with $2 \mathrm{mM}-\mathrm{MgCl}_{2}$ to prevent cell lysis. The esterase activities in the culture supernatants were generally low, about 0.01 units $\mathrm{ml}^{-1}$.

L. enzymogenes, which has been used in a number of enzyme studies (Whitaker, 1970; von Tigerstrom, 1980, 1981, 1983, 1984; von Tigerstrom \& Stelmaschuk, 1985, 1986, 1987a), was chosen for further experiments. We had noted that the composition of the medium had a great effect on the production of extracellular enzymes by L. enzymogenes (von Tigerstrom, 1980, 1983); therefore, the organism was grown in different media in order to try and increase the esterase production. The activities of the cell-associated esterase were 0.7 units $\mathrm{ml}^{-1}$ for cells grown in tryptone or yeast extract broth, 0.6 units ml $^{-1}$ for cells grown in soy peptone broth and 0.4 units $\mathrm{ml}^{-1}$ for cells grown in peptone broth or minimal medium. The supernatant esterase activities were similar $\left(0.1\right.$ to 0.2 units $\left.\mathrm{ml}^{-1}\right)$ in all the media except for tryptone broth (usually only 0.01 units, $\left.\mathrm{ml}^{-1}\right)$.

Yeast extract broth was chosen for studies of the enzyme production because L. enzymogenes grew well in this medium and produced relatively high levels of both esterases. The effects of various supplements to the growth medium on the esterase yield are shown in Table 1 . The additions had little or no effect on cell growth, but all increased the yield of the cell-associated esterase. Their effects on the activity of the supernatant esterase were more specific. Mineral oil decreased the supernatant esterase activity, but no effect was seen with tributyrin. However, Tween 20 and olive oil increased the activities, two- and sixfold, respectively. It is interesting that olive oil had a great effect on the yield of the supernatant esterase, but not on the cellassociated esterase. As will be shown below, olive oil is a substrate for the supernatant enzyme only. Therefore, $0.8 \%$ yeast extract, $0.1 \%$ olive oil was used routinely as the medium for the production of the supernatant esterase and $0.8 \%$ yeast extract, with or without olive oil, for the production of the cell-associated esterase. Mineral oil was included as a control to show that the increased activity is specific for substances that might be substrates for the enzyme. The result

\section{Table 1. Effect of supplements to the growth medium on the production of cell-associated and supernatant esterases by L. enzymogenes}

The organism was grown in $0.8 \%$ yeast extract with the additions $(0.1 \% \mathrm{v} / \mathrm{v})$ indicated. The cultures were harvested in the early stationary phase. The cell-associated esterase activities were determined in the cells after treatment with Zwittergen 3-14 and the supernatant esterase was determined in the culture supernatant.

\begin{tabular}{lcc} 
Addition & \multicolumn{2}{c}{ Esterase activity (units $\mathrm{ml}^{-1}$ ) } \\
None & 0.63 & Supernatant \\
Tween 20 & $1 \cdot 1$ & $0 \cdot 11$ \\
Tributyrin & 1.1 & 0.23 \\
Olive oil & $1 \cdot 2$ & 0.12 \\
Mineral oil & 1.0 & 0.61 \\
& & 0.051
\end{tabular}


also indicated that the increased activity in the supernatant when olive oil is added is not due to release of the enzyme from the cells in the presence of a hydrophobic substance, since it does not occur with mineral oil or tributyrin.

Further evidence that olive oil increased the production of the supernatant enzyme, rather than enhanced the release of the esterase from the cell surface, was obtained in experiments involving inhibition of protein synthesis. When olive oil was added to a culture growing in $0.8 \%$ yeast extract medium in the early stationary phase, the esterase activity in the supernatant increased twofold over the next $6 \mathrm{~h}$ as compared to the control without olive oil. This increase was prevented by the addition of $50 \mu \mathrm{g}$ chloramphenicol $\mathrm{ml}^{-1}$ and was, therefore, due to the synthesis of the enzyme. In addition, incubation of the cell-associated or supernatant enzyme with olive oil did not increase the enzyme activities, indicating that the olive oil did not activate the enzymes.

The growth of the organism and the production of the two enzymes in $0.8 \%$ yeast extract broth and $0.8 \%$ yeast extract, $0.1 \%$ olive oil are shown in Fig. 1 . The growth was followed by determining the increase in the cell-associated protein, since $\mathrm{OD}_{600}$ determinations, especially during the first $5 \mathrm{~h}$, were unreliable in the culture containing olive oil due to the interference by the emulsion. This growth corresponded to an increase in the $\mathrm{OD}_{600}$ of L. enzymogenes from 0.23 to a final $\mathrm{OD}_{600}$ of 5.3. After a short lag, the cultures grew exponentially for about $10 \mathrm{~h}$ with a generation time of 140 min.

The rate of production of the cell-associated esterase was exponential during the active growth period. Little or no enzyme was produced during the stationary phase and the yield of this esterase was approximately doubled in the presence of olive oil. Thus, the cell-associated esterase seems to be produced constitutively and its production is unaffected by catabolite repression which would be greatest during exponential growth. The production of the supernatant esterase is induced by olive oil. Since it is produced after the exponential growth phase it seems likely that the enzyme is under catabolite repression. Although catabolite repression is not understood in detail in Lysobacter and many other organisms, this interpretation is consistent with current ideas on the control of extracellular enzyme biosynthesis (Priest, 1984).

The results in Fig. 1 and Table 1 indicate that L. enzymogenes produces at least two different esterases. They do not rule out a possible precursor-product relationship between the two enzymes. However, as will be shown below, differences in electrophoretic mobilities and substrate specificities of the two enzymes makes this an unlikely possibility.

\section{$P A G E$ of esterase preparations}

The L. enzymogenes esterases differ with respect to their cellular locations, times of production in batch culture and, probably, in their biosynthetic control mechanisms, as just described. In addition, after PAGE of the crude esterase preparations in the presence of SDS each enzyme had one clearly defined band of activity (Fig. 2) and a mixture of the two resulted in the two separate bands. After prolonged incubation of the activity stain, a faint second band (with the faster mobility of the supernatant enzyme) could be observed with the cell extract. Thus, the cell extract may contain a trace of the active supernatant esterase, but the supernatant appears to be free of the cell-associated enzyme.

The supernatant esterase has a faster electrophoretic mobility and, therefore, probably a lower $M_{\mathrm{r}}$ than the cell-associated enzyme. The electrophoretic mobilities could not be used to calculate the $M_{\mathrm{r}}$ values for the enzymes since the esterase preparations were not heated in the presence of SDS before PAGE was carried out. The $M_{\mathrm{r}}$ markers were included to indicate the approximate sizes of the enzymes.

Glycerol gradient centrifugation also was carried out on the partially purified esterases. The cell-associated enzyme was found just before the ovalbumin peak and the secreted enzyme just after the ovalbumin peak. Therefore the $M_{\mathrm{r}}$ values of the esterases are quite similar: $45 \pm 5 \mathrm{kDa}$ for the cell-associated esterase and $38 \pm 5 \mathrm{kDa}$ for the supernatant esterase. 


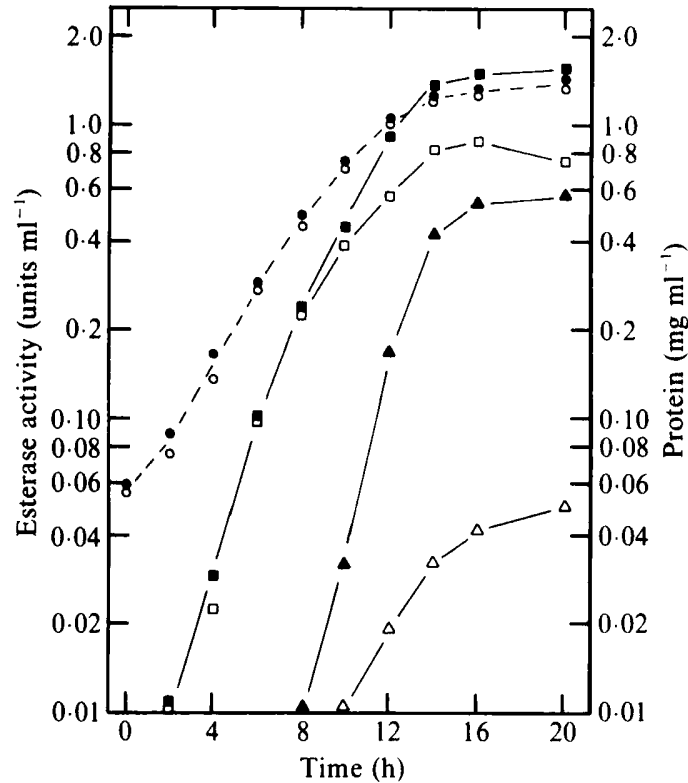

Fig. 1

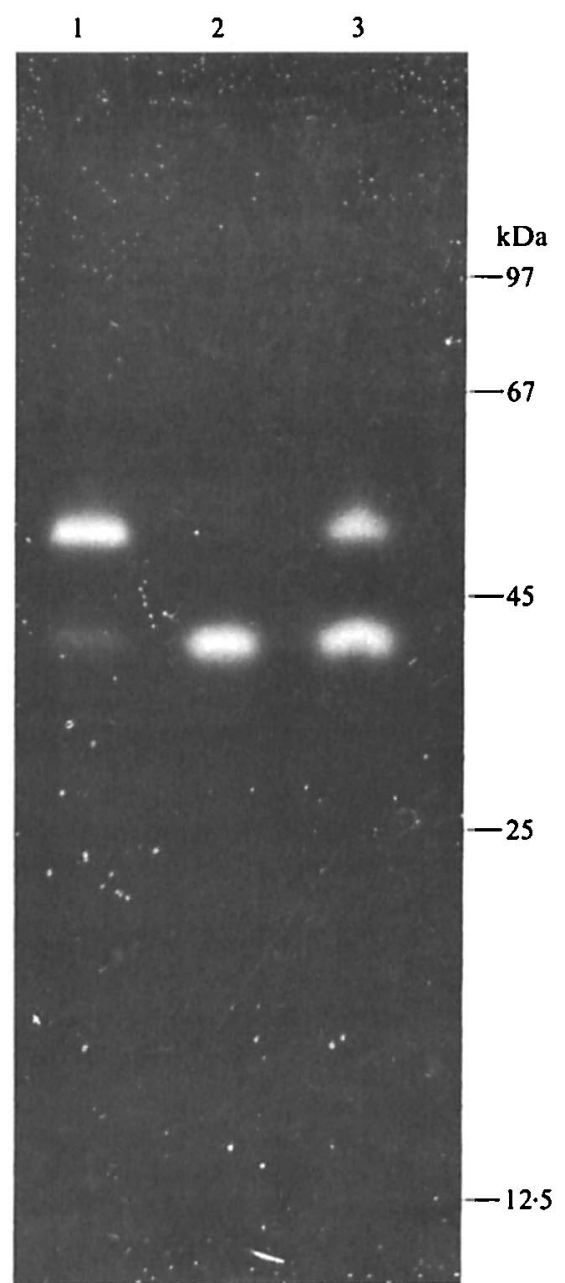

Fig. 2

Fig. 1. Growth and production of esterases by L. enzymogenes. The organism was grown in $0.8 \%$ yeast extract, $0.1 \%$ olive oil $(O)$ and $0.8 \%$ yeast extract $(O)$ and growth was determined by the increase in amount of cell-associated protein. The cell-associated esterase activities in the culture with ( $\mathbb{(})$ and without $(\square)$ olive oil and the supernatant esterase activities in the culture with $(\Delta)$ and without $(\triangle)$ olive oil were determined. This experiment is representative of two carried out with the same media. It was also carried out with $0.8 \%$ tryptone but much lower activities were obtained.

Fig. 2. PAGE. The organism was grown in $0.8 \%$ yeast extract, $0.1 \%$ olive oil and the cell-free extract and the culture supernatant were prepared as described in Methods and dialysed against 10 mm$\mathrm{Tris} / \mathrm{HCl} \mathrm{pH} 8.0$. The electrophoresis and staining of esterase activity in the gel are described in Methods. The overlay was in contact with the gel for $1 \mathrm{~h}$ at $37^{\circ} \mathrm{C}$ and the photograph was taken after $5 \mathrm{~h}$ incubation at $22{ }^{\circ} \mathrm{C}$ of the overlay alone. Lane 1 contained $20 \mu \mathrm{l}$ cell-free extract ( 0.03 esterase units), lane 2 contained $75 \mu \mathrm{l}$ supernatant $(0.03$ esterase units) and lane 3 a mixture of the two preparations. Protein staining (not shown) resulted in multiple bands for each preparation but none seemed to correspond to the activity bands. The experiment was carried out three times and was very reproducible.

\section{Localization of the cell-associated esterase}

We noted that the cell-associated esterase could be determined reliably both in cell extracts and in cells treated with Zwittergent 3-14 for 30 min to obtain maximum activity. Whole, untreated cells expressed $87 \pm 1 \cdot 7 \%$ of the maximum activity (mean $\pm \mathrm{SD}, n=3$ ). Since whole cells express much of the esterase activity, the enzyme is probably located at the cell surface, 
Table 2. Release of cell-associated esterase from L. enzymogenes cells

The additions were made to a cell suspension of $\mathrm{OD}_{600}=4 \cdot 8$. The cell suspensions were incubated for $30 \mathrm{~min}$ at $37^{\circ} \mathrm{C}$ before centrifuging a sample of each at $17400 \mathrm{~g}$ for $10 \mathrm{~min}$. The cell suspensions and the resulting supernatant solutions were assayed for esterase activities. Centrifugation immediately after the additions released $0 \%$ to $2 \%$ of the activities. Although the preincubation with Tween 20 reduces the activity, none of the compounds added interfered with the assay.

\begin{tabular}{llcc}
\cline { 2 - 3 } Addition & Total & Released & $\begin{array}{c}\text { Percentage of } \\
\text { activity released }\end{array}$ \\
None & 0.65 & $\sim 0$ & $\sim 0$ \\
Zwittergent 3-14 (to 0.2\%) & 0.75 & 0.70 & 93 \\
Tween 20 (to 2\%) & 0.37 & 0.012 & 3 \\
EDTA (to 1 mM) & 0.67 & 0.028 & 4 \\
Tween 20 + EDTA & 0.27 & 0.10 & 37
\end{tabular}

readily accessible to the substrate. An alternative explanation would be that the Tween 20 used as the substrate could have solubilized the enzyme during the assay. This was investigated and the results are shown in Table 2. The table compares the release of the esterase from whole cells exposed to Tween 20, Zwittergent 3-14 or EDTA. Only 3\% of the activity was released after 30 min incubation with Tween 20 , whereas considerably more was released with a combination of Tween 20 and EDTA, or with Zwittergent 3-14. Therefore, the results indicate that the enzyme is quite tightly bound, and active, when associated with the cell surface.

When cell-free extracts of $L$. enzymogenes were centrifuged at $48000 \mathrm{~g}$, the cell-associated esterase was mainly present in the particulate $(48000 \mathrm{~g}$ pellet) fraction. This step, and subsequent solubilization from the particulate fraction with Zwittergent 3-14, have been used to partially purify the enzyme (von Tigerstrom \& Stelmaschuk, 1989). The particulate nature of the enzyme and the solubilization with detergent indicated that the esterase might be membraneassociated.

The outer membrane and the cytoplasmic membrane of $L$. enzymogenes were separated by sucrose gradient centrifugation (Hancock \& Nikaido, 1978; von Tigerstrom \& Stelmaschuk, $1985)$ to determine the location of the particulate cell-associated esterase. The results are shown in Fig. 3. The NADH oxidase and the cell-associated phosphatase (Osborne et al., 1972; von Tigerstrom \& Stelmaschuk, 1985) were used as marker enzymes for the cytoplasmic membrane and outer membrane, respectively. In addition, KDO concentrations were determined in pooled fractions. Fractions $3-5$, fractions $6-8$ and fractions $13-16$ contained $1 \cdot 3,0 \cdot 9$, and $0.2 \mu \mathrm{g} \mathrm{KDP}$ $\mathrm{ml}^{-1}$, respectively. The results indicate that the enzyme is associated with the outer membrane of the organism.

\section{Substrate specificities}

The esterases have different substrate specificities, as indicated in Table 3. Cell-free extract was centrifuged to obtain the $48000 \mathrm{~g}$ insoluble (particulate) fraction and the $48000 \mathrm{~g}$ soluble fraction. The particulate cell-associated enzyme was most active with Tween 20 . It degraded tributyrin at a much lower rate and had little or no activity with pNPP or olive oil. The enzyme in the culture supernatant also was most active with Tween 20. In contrast to the particulate cellassociated enzyme, it degraded pNPP and olive oil relatively rapidly and tributyrin at a very low rate or not at all. The analysis of the soluble portion of the cell-free extract indicated that $L$. enzymogenes contained another lipolytic activity which was most active with tributyrin.

In an attempt to determine the location of the 'tributyrin hydrolase', we subjected whole cells to the $\mathrm{MgCl}_{2}$-shocking procedure and obtained periplasmic, particulate and cytoplasmic fractions as described in Methods. Results from two experiments indicated that the cytoplasmic fraction contained $79 \pm 3 \%$ of the 'tributyrin hydrolase' and, as expected, $93 \pm 2 \%$ of the 


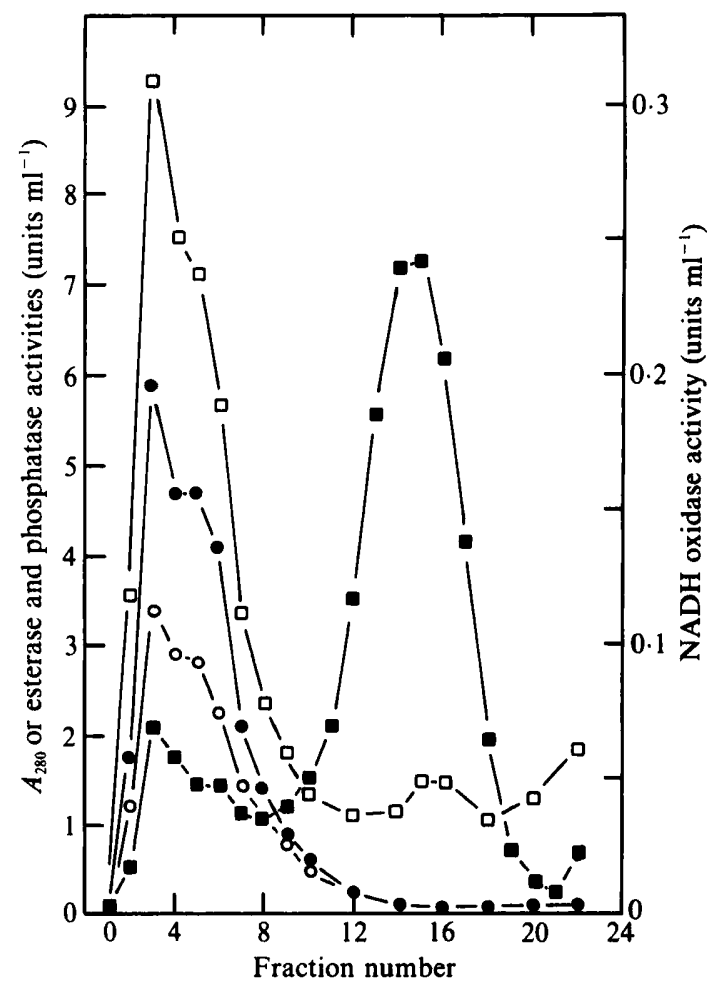

Fig. 3. Localization of the cell-associated esterase by sucrose density gradient centrifugation. Cell-free extract ( $5.7 \mathrm{ml}$ per tube) prepared from a cell suspension with an $\mathrm{OD}_{600}$ of 25 was used as described in Methods. The activity of the esterase ( $O$ ), NADH oxidase ( $\square$ ), outer-membrane-associated phosphatase (O), and the $A_{280}(\square)$ were determined. The experiment was done twice in duplicate and found to be very reproducible.

\section{Table 3. Distribution of the esterases and their activities with different substrates}

The organism was grown to early stationary phase. The esterase activities were determined in the pellet (particulate) and supernatant (soluble) fraction of cell-free extract, obtained by centrifugation at $48000 \mathrm{~g}$ for $60 \mathrm{~min}$, and in the culture supernatant. The numbers in parentheses are relative values. Activities obtained with Tween 20 were arbitrarily assigned a value of 100 .

$\begin{array}{llll} & \overbrace{\text { Particulate }}^{\text {Cell extract }} & \text { Soluble } & \begin{array}{c}\text { Culture } \\ \text { supernatant }\end{array} \\ \text { Substrate } & 0.93(100) & 0.28(100) & 0.74(100) \\ \text { Tween } 20 & 0.027(3) & 0.025(9) & 0.54(73) \\ \text { pNPP } & 0.10(11) & 2.28(814) & \sim 0(\sim 0) \\ \text { Tributyrin } & \sim 0(\sim 0) & \sim 0(\sim 0) & 0.21(28) \\ \text { Olive oil } & \sim 04)^{-1} \text { ] } & \end{array}$

marker enzyme, glucose-6-phosphate dehydrogenase. The periplasmic fraction contained $63 \pm$ $6 \%$ of the cellular $\beta$-lactamase but only $4 \pm 4 \%$ of the 'tributyrin hydrolase'. Therefore, the 'tributyrin hydrolase' appears to be cytoplasmic and probably contributes little to the extracellular esterase activity of $L$. enzymogenes. We have not attempted to further characterize this enzyme. 


\section{Purification of the esterases}

Purification of the esterases has been difficult, especially in the case of the secreted enzyme. The secreted esterase was concentrated tenfold from 2 litres of the culture supernatant by ammonium sulphate precipitation at $75 \%$ saturation. This also concentrated gummy material, probably polysaccharide, resulting in a very viscous solution and little purification. The viscosity could be decreased somewhat by vigorous homogenization in a Waring blender. Enzyme instability was a major obstacle to further purification. For example, after dialysis against $2 \mathrm{mM}$-Tris/ $\mathrm{HCl}, \mathrm{pH} 8 \cdot 0$, and ion-exchange chromatography with DEAE-Sephacel, more than $90 \%$ of the activity was lost.

The cell-associated esterase is more stable. Using cells from 2 litres of culture, the enzyme was purified 19 -fold with a $23 \%$ yield. Cell-free extract was prepared and centrifuged at $48000 \mathrm{~g}$ for 60 min to obtain crude cell envelopes containing $70 \%$ of the esterase activity. The cell envelopes were extracted with $2 \%$ Triton X-100 to remove some particulate proteins and then the esterase was solubilized with $0.2 \%$ Zwittergent in $20 \mathrm{~mm}-\mathrm{Tris} / \mathrm{HCl}, \mathrm{pH} 8.0$. It was purified by chromatography on a DEAE-Sephacel column in the presence of $0.1 \%$ Zwittergent 3-14 and by gel filtration using Sephacryl S-200. Electrophoresis of the final preparation, carried out as described for Fig. 2, indicated that many hydrophobic proteins had co-purified with the enzyme. A number of other purification methods were explored unsuccessfully. Thus, further work to try and obtain highly purified esterases in microgram quantities does not seem to be justified at this time.

Other bacterial lipolytic enzymes have been described in the literature. Sugiura (1984) reviewed the subject and reported the purification of excreted lipases from Pseudomonas fluorescens and Chromobacterium viscosum. Extracellular lipases of two other pseudomonads, $P$. nitroreducens and $P$. fragi were studied by Watanabe et al. (1977). The effect of polysaccharides on exolipase production was determined in Serratia marcescens (Winkler \& Stuckmann, 1979) and the influence of cultural conditions on the production of lipolytic enzymes in a number of microbes was reported by Sztajer \& Maliszewska (1988).

The lipolytic enzymes of Pseudomonas aeruginosa seem to be the most interesting with respect to the Lysobacter enzymes. In addition to a phospholipase (Berka \& Vasil, 1982), this organism also produces two esterases. As is the case in L. enzymogenes, one esterase is located in the outer membrane (Ohkawa et al., 1979) and the other is secreted (Stuer et al., 1986). The times of production of the $P$. aeruginosa enzymes during the cell growth cycle seem to be similar to those observed with $L$. enzymogenes and we noted recently that the two $P$. aeruginosa enzymes also are very active with Tween 20 as the substrate (von Tigerstrom \& Stelmaschuk, 1989).

The Lysobacter esterases probably have a nutritional function. They are two more enzymes in a large arsenal of extracellular hydrolases, such as proteases (Jackson \& Matsueda, 1970; Whitaker, 1970), DNA- and RNA-degrading enzymes (von Tigerstrom, 1980, 1981), phosphatases (von Tigerstrom, 1984, von Tigerstrom \& Stelmaschuk, 1986), $\beta$-glucanase and chitinase (Hedges \& Wolfe, 1974) and amylases (von Tigerstrom \& Stelmaschuk, 1987b), that these organisms produce to degrade generally high- $M_{\mathrm{r}}$ substances in their environment.

Of the many extracellular hydrolases produced by Lysobacter, some are produced in 'duplicate', one being cell-associated, the other being secreted into the medium. This was shown to be true for the two phosphatases of L. enzymogenes (von Tigerstrom, 1984) and now appears to be true also for the esterases. In both cases the cell-associated enzymes are produced constitutively, whereas the secreted enzymes are produced after the exponential growth phase. One might speculate that it is more efficient and economical for these saprophytes to have hydrolytic enzymes located at the cell surface so the cell can afford their constitutive production. Secreted enzymes may be synthesized as a 'last resort' once readily available substrates are depleted.

This work was supported by the Natural Sciences and Engineering Research Council of Canada. 


\section{REFERENCES}

BerKa, R. M. \& VASIL, M. L. (1982). Phospholipase c (heat labile hemolysin) of Pseudomonas aeruginosa: purification and preliminary characterization. Journal of Bacteriology 152, 239-245.

Chance, B. \& Maehly, A. C. (1955). Assay of catalases and peroxidases. Methods in Enzymology 2, 764-775.

Cheng, K.-J., Ingram, J. M. \& Costerston, J. W. (1970). Release of alkaline phosphatase from cells of Pseudomonas aeruginosa by manipulation of cation concentration and of $\mathrm{pH}$. Journal of Bacteriology 104, 748-753.

Christensen, P. \& Cook, F. D. (1978). Lysobacter, a new genus of non-fruiting gliding bacteria with a high base ratio. International Journal of Systematic Bacteriology 28, 367-393.

DeMoss, R. D. (1955). Glucose-6-phosphate and 6phosphogluconic dehydrogenase from Leuconostoc mesenteroides. Methods in Enzymology 1, 328-334.

Fairbanks, G., Steck, T. L. \& Wallach, D. F. H. (1971). Electrophoretic analysis of major polypeptides of the human erythrocytic membrane. Biochemistry 10, 2606-2616.

HaNCOCK, R. E. W. \& Nikaido, H. (1978). Outer membranes of gram-negative bacteria. XIX. Isolation from Pseudomonas aeruginosa PAOl and use in reconstitution and definition of the permeability barrier. Journal of Bacteriology 136, 381-390.

HeDGES, A. \& WOLFE, R. S. (1974). Extracellular enzyme from Myxobacter AL-1 that exhibits both $\beta$ 1,4-glucanase and chitosanase activities. Journal of Bacteriology 120, 844-853.

JACKSON, R. L. \& MATSUEDA, G. R. (1970). Myxobacter AL-1 protease. Methods in Enzymology 19, 591-599.

JenSEN, R. G. (1983). Detection and determination of lipase (acylglycerol hydrolase) activity from various sources. Lipids 83, 650-657.

LAW, J. H. \& SLEPECKY, R. A. (1961). Assay of poly- $\beta$ hydroxybutyric acid. Journal of Bacteriology 82, 3336.

Maizel, J. V., JR (1971). Polyacrylamide gel electrophoresis of viral proteins. Methods in Virology 5 , 179-246.

OhKawa, I., Shiga, S. \& Kageyama, M. (1979). An esterase on the outer membrane of Pseudomonas aeruginosa for the hydrolysis of long chain acylester. Journal of Biochemistry 86, 643-656.

Osborn, M. J., Gander, J. E., Parisi, E. \& Carson, J. (1972). Mechanism of assembly of the outer membrane of Salmonella typhimurium. Journal of Biological Chemistry 247, 3962-3972.

PRIEST, F. G. (1984). Extracellular Enzymes (Aspects of Microbiology, vol. 9), Washington, DC: ASM.

REICHENBACH, H. \& DWORKIN, M. (1981). The order Cytophagales (with addenda on the genera Herpetosiphon, Saprospira, and Flexithrix). In The Prokaryotes, pp. 356-379. Edited by M. P. Starr, H. Stolp, H. G. Truper, A. Balows \& H. G. Schlegel. New York: Spring-Verlag.

ROSENBERG, E. \& VARON, M. (1984). Antibiotics and lytic enzymes. In Myxobacteria, Development and Cell Interactions, pp. 109-125. Edited by E. Rosenberg. New York: Springer-Verlag.
Stuer, W., Jeager, K. E. \& Winkler, U. K. (1986). Purification of extracellular lipase from Pseudomonas aeruginosa. Journal of Bacteriology 168, 1070 1074.

Sugiura, M. (1984). Bacterial lipases. In Lipases, pp. 505-523. Edited by B. Borgstrom \& H. L. Brockman. Amsterdam: Elsevier.

SzTAJER, H. \& MaliszewsKa, I. (1988). The effect of culture conditions on lipolytic productivity of microorganisms. Biotechnology Letters 10, 199-204.

VON TIGERSTROM, R. G. (1980). Extracellular nucleases of Lysobacter enzymogenes: production of the enzymes and purification and characterization of an endonuclease. Canadian Journal of Microbiology 26, 1029-1037.

VON TIGERSTROM, R. G. (1981). Extracellular nucleases of Lysobacter enzymogenes: purification and characterization of a ribonuclease. Canadian Journal of Microbiology 27, 1080-1086.

voN Tigerstrom, R. G. (1983). The effect of magnesium and manganese ion concentrations and medium composition on the production of extracellular enzymes by Lysobacter enzymogenes. Journal of General Microbiology 129, 2293-2299.

von Tigerstrom, R. G. (1984). Production of two phosphatases by Lysobacter enzymogenes and purification and characterization of the extracellular enzyme. Applied and Environmental Microbiology 47, 693-698.

von Tigerstrom, R. G. \& Stelmaschuk, S. (1985). Localization of the cell-associated phosphatase in Lysobacter enzymogenes. Journal of General Microbiology 131, 1611-1618.

von Tigerstrom, R. G. \& Stelmaschuk, S. (1986). Purification and characterization of the outer membrane associated alkaline phosphatase of Lysobacter enzymogenes. Journal of General Microbiology 132 , $1379-1387$.

von Tigerstrom, R. G. \& Stelmaschuk, S. (1987a). Comparison of the phosphatases of Lysobacter enzymogenes with those of related bacteria. Journal of General Microbiology 133, 3121-3127.

von Tigerstrom, R. G. \& Stelmaschuk, S. (1987b). Purification and partial characterization of an amylase from Lysobacter brunescens. Journal of General Microbiology 133, 3437-3443.

von Tigerstrom, R. G. \& StelmaschuK, S. (1989). The use of Tween 20 in a sensitive turbidimetric assay of lipolytic enzymes. Canadian Journal of Microbiology 35 (in the Press).

Watanabe, N., Ota, Y., Minoda, Y. \& Yamada, K. (1977). Isolation and identification of alkaline lipase producing microorganisms, cultural conditions and some properties of crude enzymes. Agricultural and Biological Chemistry 133, 1353-1358.

WHITAKER, D. R. (1970). The $\alpha$-lytic protease of a myxobacterium. Methods in Enzymology 19, 599613.

WinkLeR, U. K. \& StuckmanN, M. (1979). Glycogen, hyaluronate, and some other polysaccharides greatly enhance the formation of exolipase by Serratia marcescens. Journal of Bacteriology 138, 663-670. 